\title{
Anticancer Effect of Essential Oil of Seed of Ferula Assa-foetida on Adenocarcinoma Gastric Cell Line
}

\author{
Seyyed Majid Bagheri ${ }^{1,2, *}$, Alia Shahmohamadi ${ }^{3}$
}

\section{Seyyed Majid Bagheri ${ }^{1,2, *}$ Alia Shahmohamadi ${ }^{3}$}

'Department Physiology, Shahid Sadoughi University of Medical Sciences, Yazd, Iran.

${ }^{2}$ Hematology and Oncology Research Center, Shahid Sadoughi University of Medical Sciences, Yazd, Iran. ${ }^{3}$ Department Physiology, International campus, Shahid Sadoughi University of Medical Sciences, Yazd, Iran.

\section{*Correspondence}

\section{Dr. Seyyed Majid Bagheri}

Department of Physiology, Shahid Sadoughi University of Medical Sciences, Prof. Hesabi Bulvd. Shohadaye Gomnam Bulvd, Yazd, IRAN.

Phone: +98 3518203410-17

Email: boss_bagheri@yahoo.com

\section{History}

- Submission Date: 11-07-2020;

- Review completed: 05-08-2020;

- Accepted Date: 22-08-2020.

DOI : 10.5530/ijcep.2020.7.3.24

Article Available online

http://www.ijcep.org

\section{Copyright}

(C) 2020 Phcog.Net. This is an openaccess article distributed under the terms of the Creative Commons Attribution 4.0 International license.

\begin{abstract}
Background and Aim: Gastric cancer is a leading cause of cancer-associated mortality in men and the incidence is also on the rise in the entire world. The present study was aimed to investigate the chemical composition of essential oil of the seed of Ferula assafoetida (EOSF) and anticancer activity of the oil on adenocarcinoma gastric (AGS) cell line. Methods: For evaluation of the cytotoxicity effect of EOSF, AGS cells were exposed to EOSF at different concentration and for different time durations. The 3-(4, 5-dimethylthiazol2-yl)-2, 5-diphenyl tetrazolium bromide (MTT) assay were carried out to characterize the cytotoxicity of the EOSF on AGS cells. In this study, the EOSF was obtained and analyzed by gas chromatography-mass spectrometry (GC-MS). Results: Our MTT assay showed that EOSF has a significant cytotoxicity activity in a time and concentration dependent manner. The main constituents of EOSF were alpha-D-Xylofuranoside, methyl 2, 5-di-O-methyl(30.2\%), E-1-propenyl sec-butyl disulfide (13.13\%) Z-1-propenyl sec-butyl disulfide (11.34\%). Conclusion: We conclude that the studied oil have a strong anticancer effect against AGS cell line. Based on the overall strong inhibition effects of the oil, isolation and studying of its compounds is suggested.

Key words: Ferula assa-foetida, Seed, Gastric cancer, Essential oil, Anticancer activity.
\end{abstract}

\section{INTRODUCTION}

Cancer is one of the leading causes of death and more than seven million deaths occur in a year, worldwide. $^{[1]}$ In cancer cells, cell cycle control becomes deregulated and cells have an imbalanced proliferation to apoptosis ratio. ${ }^{[2]}$ Gastric cancer originates from the glandular epithelium of gastric mucosa and according to global cancer statistics, gastric cancer is the fourth most frequently diagnosed cancer in men and the third most common cause of cancer-related death. ${ }^{[3]}$ Currently, there are some inefficient treatments for cancer, including surgery, radiotherapy and chemotherapy; therefore, searching to find new effective therapies and anti-cancer drugs is one of the most important aims in medicine and pharmacology, respectively. ${ }^{[4]}$ In recent years, due to relatively inexpensive and nontoxic properties of phytochemicals or chemopreventive agents with anti-cancer effects, the interest in herbal medicine has increased and more than 3000 plant species have been used to treat cancer. ${ }^{[5]}$ Some chemopreventive agents in combination with chemotherapeutic agents can enhance their anti-cancer effects at the lower doses and reduce chemotherapy-induced toxicity. ${ }^{[6]}$ Ferula assa-foetida L. is herbaceous plant of the umbelliferae family that grows wildly in the central area of Iran. ${ }^{[7]}$ It is traditionally used in the treatment of hysteria, some nervous conditions, bronchitis, asthma and whooping cough. ${ }^{[8]}$ The pharmacologically important part of this plant and several other species of Ferula is an oleo-gum-resin (asafoetida) obtained from incisions in the stem and/or roots of these plants.

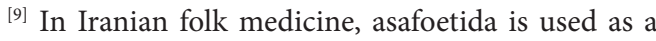
diuretic, antispasmodic, carminative and analgesic agent. ${ }^{[10]}$ Recent pharmacological and biological studies have also shown several pharmacological activities such as antioxidant, ${ }^{[11]}$ antileishmanial, ${ }^{[12]}$ cancer chemopreventive ${ }^{[13]}$ anticonvulsant, ${ }^{[14]}$ antiinflammatory, ${ }^{[15]}$ anti-diabetic, ${ }^{[16]}$ antispasmodic, ${ }^{[9]}$ hypotensive, ${ }^{[17]}$ and antinociceptive ${ }^{[18]}$ for asafoetida. Although there are a numerous studies about pharmacological effects of asafoetida, there are few studies about properties of the seed of Ferula assafoetida. In a previous study, researchers reported the antifungal activity of oil seed against some pathogenic fungi. ${ }^{[19]}$ Kassis et al. examined ethanolic extract of seed and root of Ferula assa-foetida that was called "Masculine" on male fertility and sexual functioning in rats and humans. ${ }^{[20]}$ They showed that Masculine exhibits a high level of safety in rats, humans and cultured human fibroblasts and increases erection in rats. Bagheri et al. reported that essential oil of the seed of Ferula assa-foetida (EOSF) has antispasmodic effect and this effect was stronger than oleo-gum-resin of Ferula assa-foetida. ${ }^{[9]}$ We also showed the essential oil of seed of Ferula assa-foetida exhibited a significant antinociceptive effect on chronic and acute pain in mice and concluded that 
these effects probably involve central opioid pathways and peripheral anti-inflammatory action. ${ }^{[21]}$ In this work, we studied the GC-MS analyses and the anticancer activity of EOSF on adenocarcinoma gastric (AGS) cell line.

\section{MATERIALS AND METHODS}

\section{Preparation of the Essential Oil from the Seed of Ferula assa-foetida}

Two hundred grams of seeds of Ferula assa-foetida were gently grounded and mixed with $500 \mathrm{ml}$ of double-distilled water. The essential oil was extracted by the hydro-distillation technique using a Clevenger apparatus. After extraction, the essential oil stored in hermetically sealed glass containers with rubber lids, covered with aluminum foil to protect the contents from light and kept under refrigeration at $4^{\circ} \mathrm{C}$ until used. ${ }^{[21]}$

\section{Cells and Reagents}

The AGS cells purchased from the Pasteur Institute of Iran, were maintained in Dulbecco's modified Eagle's medium (DMEM) (Gibco, USA) containing 10\% (v/v) fetal bovine serum (FBS, Gibco Laboratories), $300 \mu \mathrm{g} / \mathrm{ml}$ glutamine, $100 \mu \mathrm{g} / \mathrm{ml}$ streptomycin and 100 units $/ \mathrm{ml}$ penicillin. The cell cultures were maintained at $37^{\circ} \dot{\mathrm{C}}$ in a humidified atmosphere with 5\% $\mathrm{CO}_{2}$. The 3-(4, 5-dimethylthiazol2-yl)-2, 5-diphenyl tetrazolium bromide (MTT) were obtained from Sigma, USA.

\section{Cytotoxicity Assay}

Tumor cells were harvested from culture flasks using $0.05 \%$ Ethylenediaminetetraacetic acid (EDTA, Gibco Laboratories) for $3 \mathrm{~min}$. The cells were washed in standard growth medium and counted using a hemocytometer. A number of $2 \times 10^{4}$ cells per well were plated on 96 well flat-bottomed plates. After one day of seeding of cells at $37^{\circ} \mathrm{C}$, cells were treated for 24, 48 and $72 \mathrm{~h}$ with various concentrations of essential oil $(0.01,0.1,1,10 \mu \mathrm{l} / \mathrm{ml})$. Cells treated with serum-free medium for the same period of time were used as a control. After that, the MTT solution ( $5 \mathrm{mg} / \mathrm{ml}$ in PBS) was added to each well. The MTTs was dissolved in sterile phosphate-buffered saline at $5 \mathrm{mg} / \mathrm{ml}$ and stored in dark environment at $4^{\circ} \mathrm{C}$ for a period lasting less than 3 weeks. After the final dilution, with pre-warmed sterile un-supplemented culture medium, the MTT solution was filtered through a $0.22 \mu \mathrm{m}$ filter. After $3.5 \mathrm{~h}$ of incubation, purple crystals were formed by mitochondrial dehydrogenase enzyme of living cells. Then, the medium was discarded and $150 \mu \mathrm{l}$ of dimethyl sulfoxide (DMSO) was added to dissolve the formazan crystals. The absorbance of each sample was read at $540 \mathrm{~nm}$ using a micro plate reader (Bio Tek Instrument, Box 998). Results were expressed as percentage of cell viability with respect to untreated control cells (as 100\%). The percent viability of each cell was calculated from the following formula:

Percent viability $=\frac{\text { absorbance of test-absorbance of blank }}{\text { absorbance of control-absorbance of blank }} \times 100$

\section{Lipoxygenase Inhibition Activity of EOSF}

The soybean 15-lipoxygenase was used to test the 15-lox inhibitory activity of EOSF. For this purpose, $50 \mathrm{~mL}$ of essential oil solution was added to test solution containing $3 \mathrm{ml}$ of phosphate buffer $(0.1 \mathrm{M}, \mathrm{pH}=$ 8), $50 \mathrm{~mL}$ enzyme solution (final concentration of $167 \mathrm{U} / \mathrm{ml}$ ) to achieve the enzyme inhibition between 20 to $80 \%$. After 4 min incubation of test solution, the substrate (Linoleic acid, final concentration of $134 \mathrm{mM}$ ) was added and the change in absorbance was measured for $60 \mathrm{sec}$ at $234 \mathrm{~nm}$. The half maximal inhibitory concentration $\left(\mathrm{IC}_{50}\right)$ value was calculated graphically using the slopes of absorbance curves. The enzyme solution was kept in ice and tested at intervals to ensure that the enzyme activity was constant. All experiments were performed by UV/Vis Unico Double Beam Spectrophotometer at $25^{\circ} \mathrm{C}$ in triplicate. ${ }^{[13]}$

\section{Antioxidant Activity Assay of Asafoetida}

The antioxidant activity of EOSF was evaluated spectrophotometrically using the 2,2-diphenyl-1-picrylhydrazyl (DPPH) method. EOSF was evaluated at $100 \mathrm{mg} / \mathrm{L}$, by mixing $0.75 \mathrm{~mL}$ with $1.5 \mathrm{~mL}$ of a freshly prepared DPPH solution $(20 \mathrm{mg} / \mathrm{L})$; then, sample was mixed thoroughly and kept in the dark for $30 \mathrm{~min}$ at room temperature. After that, each mixture was tested for the DPPH radical-scavenging activity by reading the absorbance at $517 \mathrm{~nm}$ on a spectrophotometer. Blank [solution prepared by mixing $0.75 \mathrm{~mL}$ of ultra-pure water with $1.5 \mathrm{~mL}$ of the DPPH solution $(20 \mathrm{mg} / \mathrm{L})$ ] was used and read at the same wavelength. The antioxidant activity percentage was calculated following the formula:

Antioxidant activity $(\%)=[($ A Control - A oil $) / A$ Control $]$ x 100

Where A Control is the absorbance of a DPPH solution without the oil, A oil is the absorbance of the tested oil, which is equal to the absorbance of the oil plus the DPPH (20 mg/L) minus the blank extract absorbance. The samples were run in triplicate and the average of the three values was recorded. ${ }^{[22]}$

\section{Gas Chromatography-Mass Spectrometry Analysis}

The chemical composition of the essential oil was determined at the Isfahan University of Medical Sciences by GC-MS using a HewlettPackard 5971 GC/MS apparatus (Avondale, PA, USA) under the following conditions: a $0.25 \mathrm{~mm}$ x $30 \mathrm{~m}$ polydimethylsiloxane DB-1 fused silica capillary column, with a film thickness of $0.10 \mu \mathrm{m}$; helium as the carrier gas helium $(1 \mathrm{~mL} / \mathrm{min})$, injector temperature of $250^{\circ} \mathrm{C}$ and detector temperature of $200^{\circ} \mathrm{C}$. The column temperature ranged from 35 to $180^{\circ} \mathrm{C} / \mathrm{min}$, at $4^{\circ} \mathrm{C} \mathrm{V} / \mathrm{min}$ and then from 180 to $280^{\circ} \mathrm{C}$, at $20^{\circ} \mathrm{C} \mathrm{V} / \mathrm{min}$; mass spectra were obtained by electronic impact $70 \mathrm{eV}$. The constituents were identified by a computer-based library search, with retention indices and visual interpretation of the mass spectra. ${ }^{[23]}$

\section{Statistical Analysis of Data}

Statistical data were assessed with one-way analysis of variance (ANOVA), followed by post hoc Tukey's test using Graph pad prism version 5 . Results were expressed as mean \pm standard error of the mean (SEM). A value of $P<0.05$ was considered significant.

\section{RESULTS}

\section{Cytotoxic Effect of EOSF on AGS Cell Line}

To determine whether EOSF has antiproliferative effect, AGS cells were treated with various concentrations $(0.01,0.1,1,10 \mu \mathrm{l} / \mathrm{ml})$ of the EOSF for the indicated times (24, 48 and 72) and cell proliferation was determined using the MTT-based colorimetric assay. As duration and dose increases, proliferation was significantly decreased in cells treated with the EOSF, clearly demonstrating an antiproliferative effect (Figure 1). The inhibition effect of EOSF on AGS cells was enhanced after incubated for 24,48 and $72 \mathrm{~h}$.

\section{Chemical Constituents}

Analysis of the chemical composition of the essential oil by GC-MS facilitated the identification of oil components. The major compounds identified in EOSF were alpha-D-Xylofuranoside, methyl 2,5-di-Omethyl-(30.2\%), E-1-propenyl sec-butyl disulfide (13.13\%) and Z-1propenyl sec-butyl disulfide (11.34\%) (Table 1). 


\section{Lipoxygenase Inhibitory and Radical Scavenging Activity}

The lipoxygenase (LOX) activity was measured as an increase in the absorbance at $234 \mathrm{~nm}$, which reflects the formation of hydroperoxylinoleic acid. The $\mathrm{IC}_{50}$ of inhibitory activity of EOSF was $38 \mu \mathrm{g} / \mathrm{ml}$ and $\mathrm{IC}_{50}$ of antioxidant activity of EOSF was $112 \mu \mathrm{g} / \mathrm{ml}$ (Table 2).

\section{DISCUSSION}

This study set out to investigate the anti-proliferative effects of EOSF against human AGS cell line. Our results revealed that 24, 48 and $72 \mathrm{~h}$ after incubation with EOSF, cell viability was significantly decreased as dose of EOSF and time of incubation increases compared to control group (Figure 1). The cytotoxic activity of the EOSF on AGS cell line using MTT assay suggested that the oil is severely cytotoxic on AGS cells. Due to this cytotoxic effect, mortality of the cells was near $100 \%$ in $10 \mu \mathrm{l} / \mathrm{ml}$ in $72 \mathrm{~h}$ after incubation. The anti-cancer potent and chemopreventive effects of Ferula species and its derivatives have investigated in different studies. Bamehr et al. indicated that Ferula pseudalliacea extract is able to induce

\section{Table 1: Chemical Composition of Essential Oil of the Seed of Ferula assa-foetida.}

\begin{tabular}{|c|c|c|}
\hline & Library/ID & Pct Total \\
\hline 1 & .alpha.-D-Xylofuranoside, methyl 2,5-di-O-methyl- & 30.2 \\
\hline 2 & (E)-sec-Butyl propenyl disulfide & 13.13 \\
\hline 3 & (Z)-sec-Butyl propenyl disulfide & 11.34 \\
\hline 4 & Trifluoromethyl t-butyl disulfide & 6.33 \\
\hline 5 & Disulfide, bis(1-methylpropyl) & 5.47 \\
\hline 6 & 10-epi-.gamma.-eudesmol & 4.37 \\
\hline 7 & 3-Mercaptopropionitrile & 3. 28 \\
\hline 8 & Agarospirol & 3.5 \\
\hline 9 & Ethanethioamide & 2.9 \\
\hline 10 & Methyl sec-butyl disulphide & 2.75 \\
\hline 11 & 5-epi-7-epi- $\alpha$-Eudesmol & 2.62 \\
\hline 12 & 1-(Methylthio) propyl propyl disulfide & 2.53 \\
\hline 13 & (-)-Aristolene & 1.41 \\
\hline 14 & (Z)-1-(But-2-en-1-yl)-2-(sec-butyl)disulfane & 1.3 \\
\hline 15 & .alpha.-Pinene & 1.8 \\
\hline 16 & 3H-1,2-Dithiole & 1.9 \\
\hline 17 & N-propyl sec-butyl disulfide & 0.44 \\
\hline 18 & 4-(hexadecyloxy)-3-nitrobenzenesulfonyl fluoride & 0.39 \\
\hline 19 & Thiopivalic acid & 0.36 \\
\hline 20 & Benzenepropanoic acid, pentyl ester & 0.33 \\
\hline 21 & 2-Thiazolidinethione & 0.27 \\
\hline 22 & Morpholine, 2,6-dimethyl- & 0.25 \\
\hline 24 & Tridecyloxirane & 0.19 \\
\hline 25 & Elemol & 0.17 \\
\hline \multirow[t]{2}{*}{26} & Dimethyl trisulfide & 0.17 \\
\hline & Total & 94.22 \\
\hline
\end{tabular}

Table 2: Antioxidant and Lipoxygenase Inhibitory Activities of EOSF.

$\begin{array}{cc}\mathrm{DPPH}\left(\mathrm{IC}_{50}\right) & \text { Lipoxygenase Inhibition }\left(\mathrm{IC}_{50}\right) \\ 112 \mu \mathrm{g} / \mathrm{ml} & 38 \mu \mathrm{g} / \mathrm{mL}\end{array}$

apoptosis in HCT-116 cells mainly by induced apoptosis via promotion of cell cycle arrest, caspase 3 activation and destruction of mitochondria membrane potential. ${ }^{[24]}$ A coumarin (diversin) isolated from the roots of Ferula diversivittata were studied for their possible anticancer effects and results of the investigation indicated that diversin might be valuable as a potent cancer chemopreventive agent. ${ }^{[25]}$ Umbelliprenin is an another component that has shown a remarkable cancer chemoprevention in vitro and in vivo studies. ${ }^{[2]}$ Researchers assessed the cancer chemopreventive activity of umbelliprenin in vivo by using a two-stage carcinogenesis assay of mouse skin tumors ${ }^{[26]}$ and they found that cancer chemoprevention of umbelliprenin is comparable with curcumin, a well-known cancer chemopreventive agent. Ferula assa-foetida is one of the important Ferula species that grows wildly in central area of Iran and showed several biological and pharmacological activity. ${ }^{[27]}$ The oleo gum resin is most important part of Ferula assa-foetida that often obtained by incision of the roots or removal of the stems and chemical compounds can be used for treating diseases including cancer. ${ }^{[28]}$ The modulatory influences of Ferula assa-foetida oleo gum resin on the mammary epithelial tissue differentiation, hepatic drug metabolizing enzymes, antioxidant profiles and $\mathrm{N}$-methyl-N-nitrosourea (MNU)-induced mammary carcinogenesis in Sprague-Dawley rats was investigated ${ }^{[29]}$ and the findings indicated the chemopreventive potential of asafoetida against MNU-induced mammary carcinogenesis. Saleem et al. showed that pretreatment of animals with acetone extract of asafoetida could cause the reversal of early events of carcinogenesis in vivo. ${ }^{[30]}$ Another study showed that asafoetida reduced the multiplicity and size of palpable mammary tumors in Sprague-Dawley rats. ${ }^{[8]}$ Different mechanisms seem to impact on this activity such as radical scavenging activity and lipoxygenase inhibition activity ${ }^{[29]}$ and blocking the enzyme 5-lipoxygenase may be for at least part of the observed chemopreventive activity of the asafoetida and its components. Our results showed that EOSF also has remarkable antioxidant and lipoxygenase inhibitor activity. Analysis of the chemical composition of the SEOF by GC-MS showed that the oil consists of mainly alpha-D-Xylofuranoside, methyl 2,5-di-O-methyl, E-1-propenyl sec-butyl and Z-1-propenyl sec-butyl. Previously, some evidence suggests that organosulfur compounds modulate the activity of several metabolizing enzymes that activate (cytochrome P450s) or detoxify (glutathione S-transferases) carcinogens and inhibit the formation of DNA adducts in several target tissues. ${ }^{[31]}$ Sulfur compounds contained within vegetables may be chemically or enzymatically transformed in the human body with subsequent formation of hydrogen sulphide $\left(\mathrm{H}_{2} \mathrm{~S}\right)$ and their consumption has been associated to chemopreventive effects. ${ }^{[32]}$ Furthermore, epidemiological studies have shown that people assuming
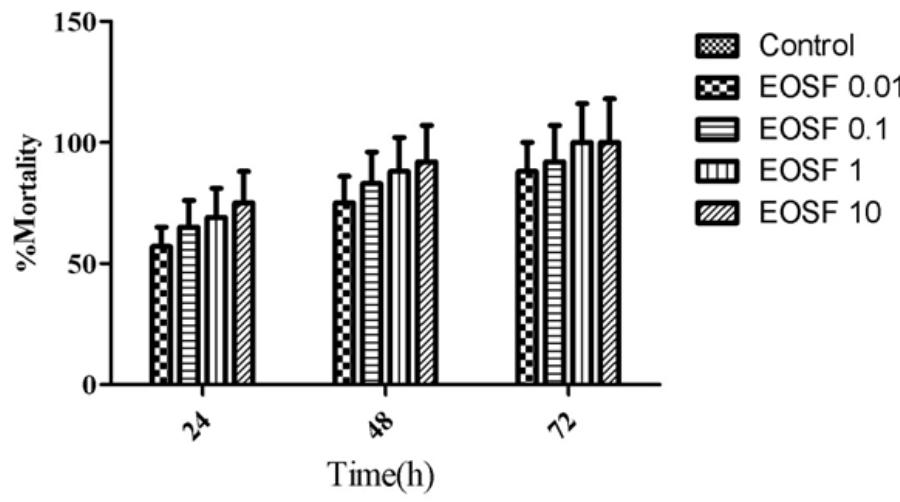

Figure 1: Cytotoxicity Effect of EOSF on AGS Cells after 24, 48 or $72 \mathrm{~h}$ Incubation.

Data was expressed as Mean \pm S.E.M

EOSF: Essential oil of seed of Ferula assa-foetida 
a diet rich in cruciferous vegetables have a minor incidence of breast, lung, prostate, colon and bladder cancer ${ }^{[33]}$ Phytochemicals rich in sulfur, in particular diet-derived compounds, have therefore been proposed and applied in clinical trials as cancer chemo preventive/ chemotherapeutic agents. These results along with studies performed using inhibitors of the enzymes responsible of $\mathrm{H}_{2} \mathrm{~S}$ production have led to hypothesize a role for this metabolic pathway in cancer. ${ }^{[34]}$

\section{CONCLUSION}

EOSF has inhibitory effect on the growth of AGS cell line and could be considered as attractive alternative to serve as compounds in drug development for gastric cancer as an adjuvant therapy. Hence, the oil can be utilized safely for therapeutic use in pharmaceutical formulations.

\section{CONFLICT OF INTEREST}

Authors declare that they have no conflict of interest

\section{ABBREVIATIONS}

EOSF: Essential Oil of the Seed of Ferula assa-foetida; AGS cell line: Adenocarcinoma Gastric cell line; MTT: 3-(4, 5-dimethylthiazol-2yl)-2, 5-diphenyl tetrazolium bromide; GC-MS: Gas ChromatographyMass Spectrometry; DMEM: Dulbecco's Modified Eagle's Medium; FBS: Fetal Bovine Serum; EDTA: Ethylenediaminetetraacetic acid; IC $_{50}$ : Half Maximal Inhibitory Concentration; DDPH: 2,2-diphenyl-1picrylhydrazyl; LOX: Lipoxygenase; MNU: N-methyl-N-nitrosourea; $\mathbf{H}_{2} \mathrm{~S}$ : Hydrogen Sulphide.

\section{REFERENCES}

1. Brenner $H$, Rothenbacher D, Arndt V. Epidemiology of stomach cancer. Methods Mol Biol. 2009;472:467-77.

2. Marks P, Rifkind RA, Richon VM, Breslow R, MillerT, Kelly WK. Histone deacetylases and cancer: Causes and therapies. Nat Rev Cancer. 2001;1(3):194-202.

3. Rugge M, Fassan M, Graham DY. Epidemiology of gastric cancer. $1^{\text {st }}$ Ed. Switzerland: Springer International Publishing. 2015;23-34.

4. Danhier F, Feron O, Préat V. To exploit the tumor microenvironment: Passive and active tumor targeting of nanocarriers for anti-cancer drug delivery. J Control Release. 2010;148(2):135-46.

5. Murakami A, Ohigashi H, Koshimizu K. Anti-tumor promotion with food phytochemicals: A strategy for cancer chemoprevention. Biosci Biotechnol Biochem. 1996;60(1):1-8.

6. Sarkar FH, LiY. Using chemopreventive agents to enhance the efficacy of cancer therapy. Cancer Res. 2006;66(7):3347-50.

7. Bagheri SM, Sahebkar A, Gohari AR, Saeidnia S, Malmir M, Iranshahi M. Evaluation of cytotoxicity and anticonvulsant activity of some Iranian medicinal Ferula species. Pharm Biol. 2010;48(3):242-6.

8. Iranshahy M, Iranshahi M. Traditional uses, phytochemistry and pharmacology of asafoetida (Ferula assa-foetida oleo-gum-resin)-A review. J Ethnopharmacol. $2011 ; 134(1): 1-10$

9. Bagheri S, Hejazian S, Dashti RM. The Relaxant Effect of Seed of Essential Oil and Oleo-gum-resin of Ferula assa-foetida on Isolated Rat's Ileum. Ann Med Health Sci Res. 2015;4(2):238-41

10. Azizian H, Rezvani ME, Esmaeilidehaj M, Bagheri SM. Anti-Obesity, Fat Lowering and Liver Steatosis Protective Effects of Ferula assa-foetida Gum in Type 2 Diabetic Rats: Possible Involvement of Leptin. Iran J Diabetes Obes. 2012;4(3):120-6.

11. Dehpour AA, Ebrahimzadeh MA, Seyed FN, Seyed MN. Antioxidant activity of the methanol extract of Ferula assa-foetida and its essential oil composition. Grasas Aceites. 2009;60(4):405-12.
12. Bafghi AF, Bagheri SM, Hejazian SH. Antileishmanial activity of Ferula assafoetida oleo gum resin against Leishmania major: An in vitro study. J Ayurveda Integr Med. 2014;5(4):223.

13. Bagheri SM, Abdian-Asl A, Moghadam MT, Yadegari M, Mirjalili A, Zare-Mohaz-

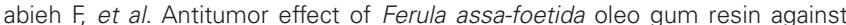
breast cancer induced by $4 \mathrm{~T} 1$ cells in BALB/c mice. J Ayurveda Integr Med. 2017;8(3):152-8.

14. Bagheri SM, Rezvani ME, Vahidi AR, Esmaili M. Anticonvulsant effect of Ferula assa-foetida oleo gum resin on chemical and amygdala-kindled rats. N Am J Med Sci. 2014;6(8):408.

15. Bagheri SM, Hedesh ST, Mirjalili A, Dashti-R MH. Evaluation of Anti-inflammatory and Some Possible Mechanisms of Antinociceptive Effect of Ferula assa-foetida Oleo Gum Resin. J Evid Based Complementary Altern Med. 2015;21(4):271-6.

16. Abu-Zaiton AS. Anti-diabetic activity of Ferula assa-foetida extract in normal and alloxan-induced diabetic rats. Pak J Biol Sci. 2010;13(2):97.

17. Fatehi M, Farifteh F, Fatehi-Hassanabad Z. Antispasmodic and hypotensive effects of Ferula ass-afoetida gum extract. J Ethnopharmacol. 2004;91(2):321-4.

18. Bagheri S, Dashti-R M, Morshedi A. Antinociceptive effect of Ferula assa-foetida oleo-gum-resin in mice. Res Pharm Sci. 2014;9(3):207.

19. Sitara U, Niaz I, Naseem J, Sultana N. Antifungal effect of essential oils on in vitro growth of pathogenic fungi. Pak J Bot. 2008;40(1):409.

20. Kassis E, Fulder S, Khalil K, Hadieh B, Nahhas F, Saad B, et al. Efficacy and safety assessments of Ferula assa-foetida L., traditionally used in Greco-Arab herbal medicine for enhancing male fertility, libido and erectile function. Open Complement Med J. 2009;1:102-9.

21. Bagheri SM, Mohamadsadeghi H, Hejazian ES. Antinociceptive effect of seed's essential oil of Ferula assa-foetida in mice. Int J Clin Exp Physiol. 2017;4(1):34-7.

22. Mensor LL, Menezes FS, Leitão GG, Reis AS, Santos TCD, Coube CS, et al. Screening of Brazilian plant extracts for antioxidant activity by the use of DPPH free radical method. Phytother Res. 2001;15(2):127-30.

23. Botelho M, Nogueira N, Bastos G, Fonseca S, Lemos T, Matos F, et al. Antimicrobial activity of the essential oil from Lippia sidoides, carvacrol and thymol against oral pathogens. Braz J Med Biol Res. 2007;40(3):349-56.

24. Bamehr H, Saidijam M, Dastan D, Amini R, Pourjafar M, Najafi R. Ferula pseudalliacea induces apoptosis in human colorectal cancer HCT-116 cells via mitochondria-dependent pathway. Arch Physiol Biochem. 2018;284-91.

25. Iranshahi M, Sahebkar A, Hosseini S, Takasaki M, Konoshima T, Tokuda H. Cancer chemopreventive activity of diversin from Ferula diversivittata in vitro and in vivo. Phytomedicine. 2010;17(3-4):269-73.

26. Iranshahi M, Sahebkar A, Takasaki M, Konoshima T, Tokuda H. Cancer chemopreventive activity of the prenylated coumarin, umbelliprenin, in vivo. Eur J Cancer Prev. 2009;18(5):412-5.

27. Bagheri S, Mohammadsadeghi H, Dashti-R M, Mousavian SM, Aghaei Z. Effect of Ferula assa-foetida oleo-gum-resin on renal function in normal Wistar rats. Indian J Nephrol. 2016;26(6):419-22.

28. Bagheri SM, Yadegari M, Mirjalily A, Rezvani ME. Evaluation of toxicity effects of asafetida on biochemical, hematological and histological parameters in male wistar rats. Toxicol Int. 2015;22(1):61-5.

29. Mallikarjuna GU, Dhanalakshmi S, Raisuddin S, Rao AR. Chemomodulatory influence of Ferula assa-foetida on mammary epithelial differentiation, hepatic drug metabolizing enzymes, antioxidant profiles and N-methyl- $\mathrm{N}$-nitrosourea-induced mammary carcinogenesis in rats. Breast Cancer Res Treat. 2003;81(1):110.

30. Saleem M, Alam A, Sultana S. Asafoetida inhibits early events of carcinogenesis: A chemopreventive study. Life Sci. 2001;68(16):1913-21.

31. Omar S, Al-Wabel N. Organosulfur compounds and possible mechanism of garlic in cancer. Saudi Pharm J. 2010;18(1):51-8.

32. Jacob C, Anwar A, Burkholz T. Perspective on recent developments on sulfurcontaining agents and hydrogen sulfide signaling. Planta Med. 2008;74(13):158092.

33. DeCicco P, Panza E, Armogida C, Ercolano G, Taglialatela-Scafati O, Shokoohinia $\mathrm{Y}$, et al. The hydrogen sulfide releasing molecule acetyl deacylasadisulfide inhibits metastatic melanoma. Front Pharmacol. 2017;8:65.

34. Szabo C. Gasotransmitters in cancer: From pathophysiology to experimenta therapy. Nat Rev Drug Discov. 2016;15(3):185-203. 